\title{
The Reform of Grass Roots Tribunals and the Application of the Law in Rural China
}

The case of the district of Weicheng, in the city of Xianyang, Shaanxi province

\section{Ding Wei}

\section{(2) OpenEdition}

\section{Journals}

Édition électronique

URL : http://journals.openedition.org/chinaperspectives/527

DOI : $10.4000 /$ chinaperspectives.527

ISSN : 1996-4617

Éditeur

Centre d'étude français sur la Chine contemporaine

Édition imprimée

Date de publication : 1 octobre 2005

ISSN : 2070-3449

\section{Référence électronique}

Ding Wei, «The Reform of Grass Roots Tribunals and the Application of the Law in Rural China », China Perspectives [En ligne], 61 | september-october 2005, mis en ligne le 01 octobre 2008, consulté le 14 novembre 2019. URL : http://journals.openedition.org/chinaperspectives/527 ; DOI : 10.4000/ chinaperspectives.527

Ce document a été généré automatiquement le 14 novembre 2019.

(c) All rights reserved 


\section{The Reform of Grass Roots Tribunals and the Application of the Law in Rural China}

The case of the district of Weicheng, in the city of Xianyang, Shaanxi province

\section{Ding Wei}

1 This article studies the role of the "special mediators" of the people's court in the district of Weicheng (Weicheng qu), in the city of Xianyang (Xianyang shi), in the province of Shaanxi. It focuses on the application of the law to the countryside. These special mediators help the grassroots tribunals carry out their political and legal functions, and their involvement in the judicial process contributes to increasing the awareness among the villagers of their rights ${ }^{1}$.

2 In rural China, the grassroots levels of the judiciary play a key role in the establishment there of the rule of law ${ }^{2}$. Indeed, contemporary Chinese law, being based on the regulation of urban society, pays little attention to the characteristics of custom-bound rural society or to local particularities. Many peasants, because of a fairly low level of education and because of their geographic and social isolation, have little legal knowledge and their understanding of the law is rudimentary. China has a rural population of 800 million, and developing legal knowledge in the countryside is no small matter. Since 1986, the Party and the state have launched extensive law awareness campaigns. But in the absence of a real network of legal information, the impact of these initiatives has remained limited ${ }^{3}$. Finding new ways to improve governance in the countryside has become a major preoccupation.

The new legal system in China

3 To understand the development of the law in contemporary China, it is necessary to begin with a retrospective analysis.

The Communist Party, politics and the law

4 At the end of the Qing dynasty, the constitutional reform movement favoured importing a Western legislative system in its entirety. However, while the total 
transplantation of a Western-style system was initially envisaged, the reality consisted of a merging of Western features (ultimately from the Soviet Union) with Chinese ones, in order to construct a legal system which would fit Chinese social reality ${ }^{4}$.

5 In Yan'an, in the 1930s, the Chinese Communist Party (CCP) already considered legal action and mediation as the most effective ways of administering society; the law had to be subject to the Party's objectives and thus serve its political aims and spread its ideology to the masses. In the particular context of the war of resistance against Japan, the CCP formed a unique legal system-the "Ma Xiwu judicial method" 5 ; the judges investigated with the help of the "enlightened" view of the "masses", set up compromises, settled controversies, and put into practice a cognitive method based on the aspirations of the people. In the absence of guaranteed rights, or of a clear distinction between legal and administrative powers, it was very easy to move to actions which were entirely controlled by the Party, or to end up with a political movement such as the Cultural Revolution ${ }^{6}$.

6 The victory of the Chinese Communist Party and the establishment of the new regime led to a reorganising of the law which founded a new tradition, both political and legal. The law and politics were closely linked; the division of labour between legal tasks on the one hand, and administrative activities and those connected to the grass roots on the other was repudiated, as was the independence of the judiciary and the administration. The law went beyond its traditional field of application to become a means of transforming society. Relying on governance by the law, the Party sought to apply its political line ${ }^{7}$.

The role of the courts

7 The courts are the most important institutions in the application of the law. But they are not autonomous in the accomplishment of this function. In practice a court can neither accept nor reject general cases which fall within its jurisdiction. Conversely, in cases that are not within its purview, even if it is keen to deal with them, it cannot do so. Looking back on decades of the existence of the courts, one finds that they have always carried out a range of "work of essential importance", in different periods ${ }^{8}$. For example the presidents of the People's Courts often larded their discourse with phrases such as "with the aim of maintaining social stability" or "making the necessary contributions to developing co-ordination at all levels between the economy and society".

8 The main function of the courts is to settle lawsuits. Moreover, in contemporary society they have the functions of control and supervision of the government, and a role as an instrument of public policy ${ }^{9}$. According to The Organic Law Concerning the Courts of the People's Republic of China (Zhonghua renmin gongheguo renmin fa yuan zuzhi fa ${ }^{10}$, the task of the courts is try criminals and to settle general lawsuits; by defending the proletarian classes they exercise the dictatorship of the proletariat, protect the possessions of the socialist people, of the working masses, protect the rights of citizens, and see to the socialist reform of the state and to the unobstructed progress of the socialist construction of public plans of action. The People's Courts "teach citizens to devote themselves loyally to the socialist fatherland, and to respect the Constitution and the law of their own free will".

9 At the same time the courts have the function of settling lawsuits and maintaining social order, and through their public judgments, an educational function. They mould the legal awareness of the masses and their conception of the law, and strive to 
transform this awareness into trust in the law, a belief to which socialist China aspires. While the former attributions correspond to an external control over organisations and the social system, the latter correspond to an internal, ideological and cultural control. The Chinese political system is based on the principle of democratic centralism under the direction of the CCP, and on the system of People's Congresses; this kind of structure makes it difficult for the courts to carry out their functions of control over government and of instruments for public policy.

The difficulties encountered by the courts

In theory, the People's Courts act independently, according to the Constitution and the law, and are not subject to any interference from administrative organs, social groups, or individuals. However, in practice, a whole range of political, administrative, financial and private factors interfere with and curtail the position and the role assigned to the courts by the Constitution ${ }^{11}$. In the course of their activity, the courts maintain relations with the political and legal committees of the CCP, the People's Congresses, and the People's Governments, at all levels. The courts' difficulties in remaining independent are clearly apparent: the judicial organs are placed under the authority and control of the organs of the Party and of the government at the same level; moreover, what are called "human, financial and material resources" are all subject to the Party. It is difficult, in such conditions, for the courts to act in an independent manner ${ }^{12}$.

11 Through the political and legal committees at lower levels, the CCP influences the courts by means of the management of human resources and of the ideological dimension ${ }^{13}$. The political and legal committees of the Party are responsible for the unification and direction of local judicial organisation, and for the management and maintenance of public order. They examine major cases, and contribute to finding solutions. They manage the cadres of the political and judicial organs ${ }^{14}$. Thus, the testing of judges, just like the judging of a case, is carried out under the supervision of the political and legal committees. The Party cadres discuss legal cases, including those currently under way, with the judges. These exchanges between government leaders and magistrates are deemed to be exchanges between members of the Party. The authorisation given to the political committees of the Party to settle major legal cases has reinforced this way of proceeding. In 1991, the CCP's Central Committee created the Committee for Governance and the Maintenance of Public Order, and coordinated with the political committees at all levels, the links between the courts and the offices of the Party.

Whether in theory or in practice, the courts are not independent from the People's Congresses at the same level. The power to appoint and dismiss held by the Permanent Committees of the People's Congresses, combined with the removability of judges, make any criticisms they make to the People's Assembly relatively sensitive ${ }^{15}$. Another reason for the influence and control of local political organs over the courts is their power to decide the financing of the latter. To sum up, the real position of the courts within existing arrangements is considerably inferior to that provided for in the Constitution; they are dependent not only on local Party committees, but also on local government organs and even on the latter's functional organs (such as the police stations $)^{16}$.

Despite this situation, the promotion of judicial reform which will ensure the independence and the equitable exercise of judicial power based on the law seems 
highly imminent, because of the extreme importance of the law for the market economy; moreover, the legal system has already become the essential means of maintaining and ensuring justice and social stability; the People's Courts are organs of the authorities which have great power to settle civil lawsuits. Judicial reform concerns two major areas: the judicial system and the modes of judgment. The former concerns the sensitive reform of the political system, which has to be carried out cautiously under the direction of the Party. Moreover, The Outlines of the Five-Year Reform of the People's Courts, promulgated on October 20th 1999 by the Supreme People's Court, did not yet mention any fundamental change in the judicial system, but once again, without calling into question the relations between the courts and local Party Committees, underlined the leadership role of the Party in judgments, as well as the obligations of jurors to comply with the Party's policies ${ }^{17}$. On the other hand, reforming modes of judgment does not necessitate any modification of the Constitution, or of the organic law. The objective is to improve the process of judgment, to allow independent and equitable verdicts, and to make the application of the law strict and fair. Reform seeks equity in the functioning of the judicial apparatus, but also effectiveness ${ }^{18}$. Consequently judicial reform, at all levels, is more concerned with modes of judgment.

Reform of the grassroots people's courts

The grassroots courts are in direct contact with the population; they are in charge of settling disputes and ensuring stability. In order to attain this objective, in the context of the reform of judgments, the court of the district of Weicheng in the city of Xianyang has established a mechanism of "special mediators" in the framework of the People's Court in Yaodian ${ }^{19}$. This reform aimed at establishing a network of relations between the law and the local population, making the magistrate's work easier and reducing the costs of legal action.

The difficulties of judges

In rural areas, magistrates at basic levels are often faced with difficulties in the settling of legal cases, such as conveying legal documents to the people they are addressed to, carrying out investigations, having the judgment enforced, etc. These difficulties are connected with social structures but also with factors such as the rearrangement of the roads and of the highway network ${ }^{20}$. During each case there appears the conflict between the peasant mind, framed by the patrilinear system, and the spirit of modern legislation, between rural customs and the law, between political correctness and the independence of the law. All this tests the magistrates at grassroots levels.

The president of the court in Yaodian, a young experienced judge ${ }^{21}$, realised that by setting up relationships between citizens and the law, it would be possible to connect the law with rural life. This would, on the one hand, help the magistrates to settle cases and disputes, and maintain order; on the other it would help villagers to better understand legal work.

The "special mediators"

The "special mediators" are either village cadres, or villagers who are recognised as trustworthy, or respected older persons. These village elites, after a short training in law, can act as jurors during cases, and as mediators at the court to settle disputes and help resolve conflicts, while acting as educators on the law for the population. Each village generally has between three and five special mediators, chosen jointly by the court and the legal administration of the locality. They carry out several functions. 

the court? For their participation in a judgment as jurors, mediators receive 8 yuan per day as compensation. "8 yuan may seem derisory to a city-dweller", the president of the court explained to me, "but to the villagers it's a lot". Moreover, working at the court as a juror bestows prestige; often they boast in front of the villagers that "they are magistrates" and they "have reached a verdict". Besides, a plaque above the door of their house indicates their function as a special mediator. This increases their prestige in the village. As with the cadres studied by $\mathrm{Su} \mathrm{Li}^{23}$, the special mediators benefit from the authority of the court to strengthen their position in the village. On the other hand, because of their knowledge of the local environment and their activities in the village, they have privileged relations with the magistrature and these private relations based on public cases make them gain enough "face".

The success of the reform

21 The reform promoted by the Weicheng court has not only made the special mediators into men of the law ${ }^{24}$. The most important thing is that it has improved and enlarged the jury system and the mediation system, and led to better legal information.

Resorting to special mediators as jurors makes it possible to breathe new life into the old jury system. During legal proceedings, the court often has difficulty finding jurors, and the latter, if with a low level of education, are not suitable ${ }^{25}$. Resorting to special mediators makes it possible to overcome these difficulties. Thanks to their role as jurors, the mediators not only acquire symbolic capital but also receive a payment of 8 yuan per day. There are thus enough incentives for the offer to be accepted.

The cases heard by the Yaodian court are mainly conjugal and family disputes, disputes about commercial contracts, rentals, or inclusive land leases (tudi chengbao hetong) and damages for physical injuries; these cases are fairly simple and easy to untangle. The special mediators, particularly those who have had training, are quite competent to take on the duties of jurors. As such, they provide the court with their knowledge of local particularities and reliable information on the parties in conflict; they are careful to analyse and judge according to moral criteria, as well as to share their thinking with the principal judge. This process assures a verdict in conformity not only with the law (hefa), but also with common sense (heqing heli).

The work of popular mediation is essentially within the purview of the popular mediation committee (renmin tiaojie weiyuanhui) of the locality of the dispute. In the locality of Yaodian, the work of popular mediation is the responsibility of the legal administration (the General Legal Bureau), but because of lack of resources, this mediation work has little impact ${ }^{26}$. Besides, the nature of the disputes has also changed under the effects of the transformations in conditions of production and in the social 
fabric; some traditional conceptions of popular mediation and the situation of popular mediators no longer meet today's needs ${ }^{27}$. More specifically, the legal status and the effectiveness of mediation have declined: it can only settle minor disputes, and has hardly any usefulness in economic disputes, or even in simple cases of debt.

Moreover, some plaintiffs fear that an agreement obtained by mediation may have but little legal weight and may not be enforced, and that recourse to a lawsuit may be necessary all the same ${ }^{28}$. As the grassroots courts are responsible for overseeing the work of the popular mediation committees, in settling civil disputes, they have a status of authority. Consequently, reforming mediation in the courts has great significance for the progress of popular mediation ${ }^{29}$. The special mediators are capable of successfully guiding the work of reflection of each of the parties; coming from the same rural background, it is easy for them to understand exactly the situation in the village concerned and the intentions of each of the parties concerned. The mediation of the court earns the understanding and support of the people, while providing a timely solution to disputes. Interestingly, village special mediators and popular mediators are often the same people; the special mediators can thus begin mediation before the dispute reaches the court, and thus reduce the workload of the grassroots courts. For the moment, that fact that the special mediators use the prestige of the court to extend the work of mediation, leads in reality to popular mediation choosing first of all the path of mediation by the court; the work of mediation is thus made much more effective, because in the eyes of the parties concerned, the special mediators are agents of the court, with much more prestige than the popular mediators; the coincidence of the two identities makes popular and legal mediation blend together.

In Yaodian, legal education does not seem to have a very important place in the legal bureau's daily work ${ }^{30}$. Not enough importance is given to the work of popularisation, this also being due to a lack of financial resources. In this context, the legal information initiative undertaken every year by the Legal Bureau consists mainly of texts copied out on blackboards. Since June 2004, the Legal Bureau and the primary and secondary schools of the locality have agreed to stage mock court cases, an activity which carries four credits in the school syllabus. Initiatives aimed at schools are important in the work of education, but it is even more urgent to improve knowledge of the legal system among adults.

The special mediators have established a network to disseminate information on legislation in the countryside. By participating in cases as jurors, recipients follow the judicial process and become aware of the sacred character of the law and of the solemnity of the court. They thus have much more confidence and experience when they talk to the villagers about the law. Since they live in the villages, they can be found everywhere, even out in the fields. They can back up the institution of the law by "by using offences to explain the law" and transmit by word of mouth the legal knowledge they have acquired during the course of their legal practice. They thus bring the work of legal information into the real world, helping to convince parties in conflict to stop legal proceedings, to settle disputes without delay, and thus increase the effectiveness of the legal apparatus. These achievements were not all foreseen in a rational manner: they also owe much to chance, stemming from the principle of "feeling your way forward" (mozhi shetou guohe).

The application of the law in the countryside 
The special mediators' main task is to resolve differences between villagers by reconciliation, in the most moderate way possible. Thus the courts can successfully accomplish the governance of society and guarantee the political stability of the countryside.

The priority given to mediation

"Mediation not only settles disputes between individuals, but can also reduce disputes, which are considered an obstacle to the construction of a socialist State" ${ }^{31}$. According to one expert "the Communist Party has integrated mediation into its efforts to reorganise Chinese society and mobilise the masses around support for the Party's policies" ${ }^{\prime 2}$. In the district of Weicheng, the number of cases settled by mediation has become a measure of the success of the work of magistrates ${ }^{33}$. It follows that magistrates are more favourable to settlement by mediation than to settlement by judgment. In their view, the verdict in cases settled in this way, compared to those settled by judgment, is better accepted by the parties in conflict, which makes its application easier. Short, and more effective, mediation is highly suited to the work of courts in areas where resources are scarce.

Here are two examples.

In the first case, Du Zhenxing, from the village of Ximao in the locality of Yaodian, leased in 1989 a plot of land of about $200 \mathrm{mu}$ within the framework of household responsibility contracts (WW, chengbao). $60 \mathrm{mu}$ of this plot, lying between the villages of Dengjia and Dazhai, originally belonged to Dengjia, and the inhabitants of Dengjia considered that they had the right to take this land back. The dispute had lasted for years without solution. In early 2003, the villagers were getting ready to take the land back by force, destroy the crops and equipment, and resort to eviction. This extreme behaviour was very likely to lead to bloodshed, and to turn into a criminal case. The special mediators of the village, Li Jixiao (who was also the village's CCP secretary, and in charge of the special mediators and civil mediators of the village) and Li Jihong, had informed the villagers more than once about the laws in force, and emphasised that land disputes had to be resolved by legal means.

The situation was beginning to calm down, when Ti Abang and about ten other villagers, who considered that they were within their rights, sent an ultimatum in June 2003 to the local government and to Du Zhenxing, demanding that the land be given back to them. Then they took over the $60 \mathrm{mu}$ of land by force. On August 12th 2003, the court in Yaodian received a complaint against Li Jixiao, the Party secretary in Dengjia, made by $\mathrm{Du}$ Zhenxing, claiming breach of the land use contract. The court was informed of the ins and outs of the case thanks to the special mediators Li Jixiao and Li Jihong. With their help, the magistrates and the villagers had several discussions, with the villagers finally coming to an understanding that taking arable land by force was illegal, and that they had violated Du Zhenxing's right to exploit the land. They gave the land back on their own initiative.

In the second case, the court in Yaodian registered three complaints in succession: that of Sun Caijia of the village of Huangjiagou, registered against Jiao Xinli, from whom Sun demanded damages for physical injury, then that of Jiao Xinli and Liu Bimin against Wang Wenhua and Wang Wenquan, from whom they claimed damages for material losses; and finally, that of Jiao Guangli and Zhang Fengjia against Sun Caijia and Wang Wenquan, claiming damages for physical injury. These three cases were interconnected and could have led to violent clashes between lineages. The Sun and Jiao families are 
neighbours and had had ordinary disagreements from which the disputes arose. Jiao Xinli wounded Sun Caija whose sons, Wang Wenhua and Wang Wenquan, as soon as they heard the news, rushed over to the Jiao's house, where they broke furniture and killed and wounded livestock. Shortly afterwards Sun Caijia and Wang Wenquan attacked Jiao Xinli, his elder brother Jiao Guangli, and his sister-in-law Zhang Fengjia. After registering their complaints, the court immediately contacted Zhang Qingjun, the village's special mediator. He explained the case in detail, and then assisted the judge in his decision. Thanks to the combined efforts of the magistrate and the special mediators, the Sun and Jiao families finally reached an agreement, which guaranteed that there would be no further disputes.

These two cases-one of theft of land, the other of relations between neighbours turning to physical confrontation for trivial reasons-suggest that the villagers tend to resort to force in order to settle disputes. Civil disputes can become acrimonious and turn into criminal offences, threatening people's safety and social stability in the villages. According to the judges, the first objective to be considered is politicalensuring social stability; only after this comes the legal objective-recognising rights, and achieving planned justice. Undoubtedly, in simple civil cases, in which it is easy to untangle truth from falsehood or to determine responsibility, the judge can reach a verdict in accordance with the law without great difficulty. But the main problem lies in the need to convince the parties in dispute. The villagers find a fair and reasonable mediated agreement more convincing than a verdict. This explains why the special mediators, whose legal knowledge is far from extensive, can play an effective role in settling disputes-prestige and experience are much more useful in their work than legal knowledge.

China has a population of 800 million in the countryside, as well as being a state where modernisation has been only recent and initiated from abroad. In a context in which separation between the city and the country remains de rigueur, Chinese society is still extremely unequal. Contemporary law, built up to regulate urban society, works fairly homogenously in a city environment. Moreover, business dealings between civil partners who did not previously know each other mould the legal awareness of city dwellers and their conception of the law. Consequently, they have a better awareness of their rights and greater legal knowledge than the rural population ${ }^{34}$. In the cities, legal activities have become specialised and a body of legal professionals has formed. Governance in accordance with the law is no longer limited to maintaining public order and ensuring social stability, it is gradually moving towards ensuring the rights of citizens.

In the countryside, the situation is different. In a rural society which is in the process of differentiation, even though the market economy is growing stronger by the day, and even if its development increases demand from the countryside to the government for their rights to be acknowledged and honoured, and raises their expectations and their degree of organisation, the power of the government remains ubiquitous. Although the initiatives aimed at increasing knowledge of the law carried out over several years have raised the legal awareness of peasants, they are still ignorant of their rights ${ }^{35}$. It is therefore necessary, while informing them, to continue to stimulate their awareness of their rights. There is still a large gap between the reform of the mediator system and the objective of professionalisation and specialisation of the law. However this kind of innovation in the rural environment is valuable; it contains the seeds of a change in 
ways of thinking. And it is in a state where the rights of citizens are guaranteed that society is most stable.

\section{NOTES}

1. This article was presented at the international conference of doctoral candidates organised in January 2005 at the Chinese University of Hong Kong by the Universities Service Centre (USC). Guo Jun and Liu Weiha, who are judges at the People's Court in the dictrict of Weicheng (Xianyang), provided help which was essential to this research. Professor Kuan Hsin-chi of the USC and Mme Xiong Jingming helped with the writing. Professors Wu Yi and Jia Xueling of the Department of Sociology at the Central China Science and Technology University gave valuable advice. Discussions with my fellow students $\mathrm{Hu}$, Yi and Tan were very helpful. Yuan Jing helped me during the correction of the article. My thanks go also to Dr. Stéphanie Balme of the Department of Political Science and Administration at the Chinese University of Hong Kong.

2. Su Li, Song fa xiaxiang: Zhongguo jiceng sifa zhidu yanjiu (Applying the law in villages: a study of the legal system at the grassroots level in China), Peking, Zhongguo zhifa daxue chubanshe, 2000, pp. 7-11.

3. Cf. Tan Tongxue, "Xiangzhen jigou shengzhang de luoji" (The logic of the development of organs in localities and villages), in Li Changping, Tong Leiming (eds.), Shuifei gaige beijing xia de xiangzhen tizhi yanjiu (A study of the workings of localities and villages in the framework of tax reforms), Wuhan, Hubei renmin chubanshe, 2004, pp. 218-222.

4. Huang Zongzhi, "Bolun shehui yu xiandai chuantong" (Contradictory society and contemporary tradition), Dushu, No. 2, 2005, p. 13.

5. Ma Xiwu invented "itinerant" justice in the 1940s, for which no structures-such as court buildings-were necessary.

6. Ibid. pp. 9-10.

7. Qiang Shigong, Fazhi yu fali-guojia zhuanxing zhong de falü (The legal system and governance-the law in a changing country), Peking, Zhongguo zhengzhi daxue chubanshe, 2003, p. 78, pp. 123-133.

8. Jia Weifang, Sifa de linian yu zhidu (Principles and Legal Systems), Peking, Zhongguo zhengfa daxue chubanshe, 1998, pp. 105-113.

9. Zuo Weimin, Zhou Changchun, Bianqian yu gaige - fayuan zhidu xiandaihua yanjiu (Changes and Reform - A Study of Court Modernisation), Peking, Falü chubanshe, 2000, pp. 95-105.

10. This law has not been significantly changed since 1983, and evidence suggests that some of its clauses no longer fit contemporary reality. Shen Deyong, vice-president of the Supreme People's Court, emphasised on August $31^{\text {st }} 2004$ during a lecture on the amendment of The Organic Law Concerning People's Courts, that the amendment of this law was an important task in both political and legal terms. Renmin fayuan bao (Journal of The People's Courts), September $1^{\text {st }} 2004$. 
11. Yang Fengchun, Zhongguo zhengfu gaiyao (Outline of the General Policy of the Chinese Government), Peking, Peking daxue chubanshe, 2002, p. 296.

12. Jia Weifang, op. cit., p. 297.

13. Fan Sishen, "Zhongguo fayuan xitong gaiguan" (The General Situation of Chinese Courts), Liang Zhiping (ed.), Fazhi zai Zhongguo : zhidu, huayu yu shijian (The Legal System in China: Workings, Discourse and Enforcement), Peking, Zhongguo zhengfa daxue chubanshe, 2002, p. 162.

14. Yang Fengchun, op. cit., p. 296.

15. Fan Sishen, op. cit., pp. 163-167.

16. Yang Fengchun, op. cit., p. 298.

17. Fan Sishen, op. cit., p. 183.

18. Wang Liming, Sifa gaige yanjiu (A Study of Legal Reform), Peking, Falü chubanshe, 2001, pp. 314-316.

19. On April $16^{\text {th }} 2003$, the court in Weicheng opened a recruitment room for special mediators and distributed contracts to candidates. The court in the locality of Yaodian, in the district of Weicheng in Xianyang, is administered by the localities of Yaodian, Weicheng and Zhengyang. It is one of two courts which is hierarchically below that of the district of Weicheng. In rural areas, there is one People's Court for two or three localities or for 50,000 inhabitants. The People's Court is a constituent part of the grassroots People's Court, as well as its separate organ. It passes the same sentences and makes the same legal decisions. Each People's Court has at least three magistrates and a clerk. Cf. Yang Fengchun, op. cit., p. 268.

20. Su Li, op. cit., pp. 314-315.

21. This judge, born in 1970 is the only one in the court to hold a Masters degree in law; he presently occupies the post of vice-president of the criminal section of the locality's court.

22. In 2003, the court in Yaodian settled 153 cases out 178, including 119 civil cases (WWW, minshi anjian). 60 civil cases (50.4\%) were settled by agreement and 38 (31.9\%) after a trial; 55 civil cases were settled by means of simple procedure (46\%).

23. $\mathrm{Su} \mathrm{Li}$, op. cit., p. 47.

24. The special mediators cannot join any of the categories of officers of the law listed by $\mathrm{Su} \mathrm{Li}$, and they make use of only their own skills. Su Li, op. cit., pp. 299-321.

25. Wang Liming, op. cit., p. 435.

26. Interview with the director of General Legal Bureau of Yaodian, Nanning, November $3^{\text {rd }}$ 2004. In his view, the Bureau has not settled the question of allocation of funds, and salaries are not paid punctually. He adds that now, with the market economy, the mediators in each village are much more realistic than before. The court can collect legal fees, which constitute a considerable source of funds. The work done by the special mediators is much more proactive than that of the civil mediators.

27. Liang Dechao (ed.), Renmin tiaojie (A Study of Popular Mediation), Jinan, Shandong renmin chubanshe, 1999, pp. 172-176.

28. Fan Yu, Fei susong jiufen jiejue jizhi yanjiu (A study of the workings of the settlement of disputes not subject to legal proceedings), Peking, Zhongguo renmin daxue chubanshe, 2000, p. 482.

29. Liu Guang'an, Li Cunpeng, "Minjian tiaojie yu quanli baohu” (Social Mediation and the Protection of Rights), in Fu Yong (ed.), Zouxiang quanli de shidai (Towards The Era of Rights), Peking, Zhongguo zhengfa daxue chubanshe, 2000, p. 285. 
30. In the fairly elementary units of the legal office in Yaodian (the General Law Bureau) it is easy to see, from the wall posters that there are three major areas of work: (1) that of civil mediation carried out autonomously; (2) that of the special mediators who share responsibility with the people's court in Yaodian; (3) public security work carried on jointly with the police station in Yaodian.

31. Robert F. Yeutter, "Zhongguo falü jiufen de jiejue" (The settlement of legal disputes in China) in Zhang Zhongqiu (ed.), Zhongguo falü xingxiang de yimian : waiguoren yanzhong de Zhongguo fa (One facet of Chinese law: Chinese legislation as seen by foreigners), Peking, Falü chubanshe, 2002, p. 263.

32. Lu Sili, "Mao Zedong yu tiaojie: gongchanzhuyi Zhongguo de zhengzhi he jiufen jiejue" (Mao Zedong and mediation: the politics of the People's Republic and the settlement of disputes), in Qiang Shigong (ed.), Tiaojie, fazhi yu xiandaixing : Zhongguo tiaojie zhidu yanjiu (Mediation, legislation and modernity: a study of the Chinese system of mediation), Peking, Zhongguo fazhi chubanshe, 2001, p. 121.

33. For example in the "Details of the regulations concerning the application of the assessment and examination of posts of responsibility in 2005" drawn up by the court, the quota of evaluation of the success rate for resolution of cases by mediation reached $70 \%$.

34. Gao Hongjun, "Zhongguo gongmin quanli yishi de yanjiang" (The evolution of the awareness of their rights among Chinese citizens), in Xia Yong (ed.), Zouxiang quanli de shidai (Towards The Era of Rights), Peking, Zhongguo zhengfa daxue chubanshe, 2000, p. 78.

35. Gao Hongjun, op. cit., p. 79.

\section{RÉSUMÉS}

This article studies the role of the "special mediators" of the people's court in the district of Weicheng, in the city of Xianyang, in the province of Shaanxi. It focuses on the application of the law to the countryside. These special mediators help the grassroots tribunals carry out their political and legal functions, and their involvement in the judicial process contributes to increasing the awareness among the villagers of their rights. 